Cunningham, M. A., and D. H. Johnson. 2019. Narrowness of habitat selection in woodland and grassland birds. Avian Conservation and Ecology 14 (1):14. https://doi.org/10.5751/ACE-01372-140114

Copyright (C) 2019 by the author(s). Published here under license by the Resilience Alliance.

Research Paper

\title{
Narrowness of habitat selection in woodland and grassland birds
}

\author{
Mary Ann Cunningham ${ }^{1}$ and Douglas H. Johnson ${ }^{2}$ \\ ${ }^{1}$ Department of Earth Science and Geography, Vassar College, Poughkeepsie, New York, USA, ${ }^{2}$ Department of Fisheries, Wildlife, \\ and Conservation Biology, University of Minnesota, St. Paul, Minnesota, USA
}

\begin{abstract}
Conservationists have long been concerned about population declines among both woodland and grassland birds, especially those that require extensive areas of a preferred habitat type and avoid mixed habitats. Of the two groups, grassland species have declined even more rapidly than woodland species. We examined whether requirements for uninterrupted habitat could contribute to the greater population declines among grassland birds. To do this, we plotted frequency of occurrence in relation to tree cover in the landscape to evaluate narrowness of range in habitat selection, or stenotopicity, for woodland and grassland species. We created plots at three scales of $200 \mathrm{~m}, 400 \mathrm{~m}$, and $1200 \mathrm{~m}$ around bird observations. At all scales, the most stenotopic woodland species had thresholds of occurrence of 10-30\% tree cover. In contrast, most grassland species had thresholds of $80-90 \%$ grassland. Favored ranges of grassland species were also narrower than those of woodland species. Grassland species thus are dramatically more stenotopic than woodland species. Although habitat loss is a serious consideration for both groups, grassland birds face a double vulnerability, with high sensitivity to habitat extent as well as extreme habitat loss. This study highlights the importance of increasing systematic strategies to conserve grassland habitat at the regional scale.
\end{abstract}

\section{Spécificité de la sélection d'habitat par les oiseaux forestiers et de prairies}

RÉSUMÉ. Depuis longtemps, les conservationnistes sont préoccupés par les diminutions de populations d'oiseaux forestiers et de prairies, particulièrement ceux qui recherchent de vastes étendues de leur type d'habitat préféré et évitent les milieux mixtes. Parmi ces deux groupes, les espèces de prairies ont diminué encore plus rapidement que les espèces forestières. Nous avons examiné si le besoin d'un habitat homogène pouvait contribuer aux baisses plus prononcées des oiseaux de prairies. À cette fin, nous avons mis en relation la fréquence d'observation et le couvert forestier dans le paysage pour évaluer la spécificité de la sélection d'habitat, soit la sténotopicité, des espèces forestières et de prairies. Nous avons défini des zones de $200 \mathrm{~m}, 400 \mathrm{~m}$ et $1200 \mathrm{~m}$ autour des observations d'oiseaux. À chaque échelle, les espèces forestières les plus sténotopiques avaient des seuils de présence à 10-30 \% de couvert forestier, alors que la plupart des espèces de prairies avaient des seuils à 80-90\% de prairies. Les fourchettes favorites des espèces de prairies étaient aussi plus étroites que celles des espèces forestières. Les espèces de prairies sont donc carrément plus sténotopiques que les espèces forestières. Bien que la perte d'habitat soit une préoccupation importante pour les deux groupes d'espèces, les oiseaux de prairies sont doublement vulnérables, car ils sont sensibles à l'étendue d'habitat et font face à une perte considérable d'habitat. Notre étude souligne l'importance de favoriser les stratégies ciblant la conservation systématique de prairies à l'échelle régionale.

Key Words: area sensitivity; grassland birds; habitat fragmentation; loess; stenotopicity; woodland birds

\section{INTRODUCTION}

Conservationists have long been concerned about population declines of both woodland birds and grassland birds in North America. Of these two groups, grassland birds have declined even more sharply than woodland birds (NABCI 2014, Sauer et al. 2017). In the North American Breeding Bird Survey (1966-2015, survey-wide), $33 \%$ of woodland species analyzed had negative trend estimates (and 33\% positive), but $64 \%$ of grassland species had negative trends (and none was positive; Sauer et al. 2017). Here we propose that one factor influencing the greater losses among grassland birds is that their habitat requirements are narrower than those of woodland birds.

Population declines in many species are associated with reductions in the quantity and quality of their breeding habitat. This relationship has been demonstrated both for woodland birds (Whitcomb et al. 1981, Robbins et al. 1989, Donovan and Flather 2002, Desrochers et al. 2010, Rittenhouse et al. 2010) and for grassland birds (Herkert 1994, Johnson 2001, Johnson and Igl 2001, Ribic et al. 2009a). Of these groups, however, greater attention has been given to woodland species' requirements for expansive, uninterrupted habitat areas.

Among the many causes of woodland habitat loss and fragmentation are forest management practices (McWethy et al. 2009), energy development (Thomas et al. 2014, Barton et al. 2016), and exurban development (Suarez-Rubio 2013). Causes for declines in grassland habitat include conversion of grasslands to other land uses, especially agriculture (Drum et al. 2015), energy development (Hamilton et al. 2011), and fragmentation due to expansion of tree cover (Johnson 1996, Winter et al. 2000, Faber et al. 2012, Beck et al. 2016). Encroachment of woodlands into grassland habitat can be an important factor because many grassland birds avoid tree cover in the landscape even at greater distances (Grant et al. 2004, Cunningham and Johnson 2006, Beck et al. 2016). Although forest lands in North America have 
undergone extensive conversion (Ramankutty et al. 2010), losses of certain grasslands have been even greater: for example, more than $95 \%$ of tallgrass prairie in the United States has been converted to agriculture and other uses. In addition, less than $2 \%$ of remaining grasslands are on public lands (Samson et al. 2004). Because a majority of grassland birds rely on private lands for breeding habitat (Ribic et al. 2009b, Hill et al. 2014, Drum et al. 2015), they are especially vulnerable to continuing land conversion in agricultural regions (Faber et al. 2012).

Along with reduced availability of habitat, area sensitivity may be a contributing factor in the severe decline of grassland bird populations. Species that require expansive, unbroken, or uninterrupted areas of habitat, whether woodland or grassland, typically are of great conservation concern (Johnson and Temple 1990, Robinson 1995). Such species have been described as area sensitive, that is, selecting breeding territories within large areas of suitable habitat (Robbins et al. 1989, Ribic et al. 2009a). Area sensitivity has been widely considered an important factor in species declines for both woodland birds and grassland birds (Robbins et al. 1989, Johnson and Igl 2001, Ribic et al. 2009a). Area sensitivity is a term that has been used in two somewhat different ways: The term can indicate that a species requires large, unbroken habitat areas or patches (e.g., Whitcomb et al. 1981, Robbins et al. 1989) or that a species simply requires a high proportion of a preferred habitat type in the landscape, possibly including multiple adjacent patches (e.g., Villard 1998, Desrochers et al. 2010). The latter use of the term makes it possible to evaluate species that occupy the dominant (or matrix) land cover type: in a grassland interspersed with patches of woodland, for example, there is no straightforward way to calculate the area of the "patch" that comprises the dominant grassland land cover. This usage also assumes that individual birds could make use of multiple nearby habitat patches in the landscape. This second concept of area sensitivity, a preference for a high proportion of preferred habitat in the landscape, is thus a more useful approach to the concept when habitat does not clearly comprise isolated, island-like features.

A related concept is that of stenotopicity, or narrowness in range of tolerance. In the context of habitat selection in a mixed landscape, for example, an individual may make use of multiple habitat patches in a mosaic, but there may still be narrowness in the range of how much, say, a grassland bird tolerates intrusions of trees into open habitats. Conversely, a woodland bird may have wide or narrow tolerance for openings in wooded habitat. In assessing a variety of species occupying mixed landscapes, then, stenotopicity is a relatively precise concept that can be applied to narrowness of tolerance in habitat selection for woodland, grassland, or mixed-habitat species.

In this study we examined stenotopicity in woodland and grassland species occurring in landscapes of mixed habitat types. We did this first in a mixed grassland-woodland environment in eastern North Dakota, USA. Because that area might have lacked woodland species with low tolerance for open or mixed habitats, we repeated the study in a dominantly wooded environment in eastern New York State, USA. These two contrasting study areas allowed us to study tolerance of mixed habitat in both grassland and woodland species, both in a grassland-rich environment and in a woodland-rich environment. Assessing two different environments was important because context may influence observed patterns. For example, birds may be less selective about habitat extent when their preferred habitat is abundant, e.g., woodland birds may be more tolerant of open areas in a mostly wooded environment (Cunningham and Johnson 2016). Our null hypothesis was that there would be no difference in stenotopicity between the two groups (woodland and grassland species). Our alternative hypothesis was that stenotopicity of the two groups would differ.

We assessed stenotopicity by plotting species incidence in relation to extent of tree cover. Incidence plots distinguish species that occupy mostly wooded habitat from those that occupy more mixed environments (Cunningham and Johnson 2012). Here we extend that analysis to include grassland birds. For woodland species, the frequency of occurrence should be expected to increase as extent of woodland habitat in the surrounding landscape increases (Fig, 1, curve A). For area-sensitive grassland species, frequency of occurrence should decline with increasing tree cover (Fig. 1, curve B). Species that occupy mixed or edge habitat would be likely to peak or asymptote at some intermediate range of tree cover. Incidence plots thus indicate the degree to which species avoid landscapes with a reduced amount of their preferred habitat.

Fig. 1. Incidence, or probability of occurrence, can vary with increasing abundance of a key cover type. When the $\mathrm{X}$ axis represents tree cover, woodland species would be expected to follow a pattern somewhat like line A, and grassland species would be expected to follow a pattern somewhat like line B.

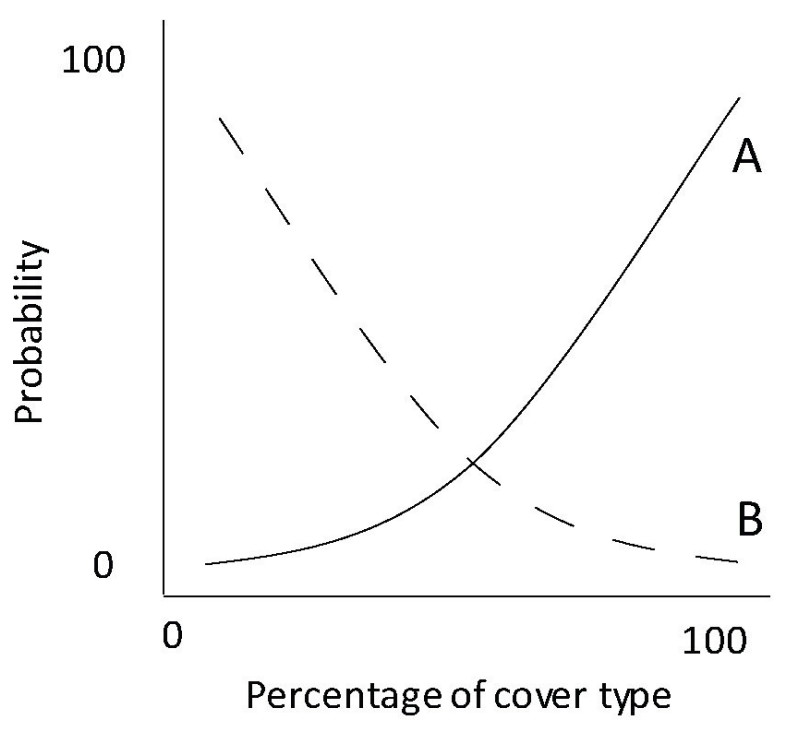

\section{STUDY AREA AND METHODS}

We selected two study areas, a mixed grassland-woodland landscape in eastern North Dakota and a mostly wooded environment in eastern New York State. The North Dakota (ND) study area was the Sheyenne National Grassland, in southeastern North Dakota, USA (46.4 N, 97.3 W). This area comprises 28,400 ha of publicly owned, largely open grassland interspersed with 
patchy upland woodlands and densely wooded riparian corridors. The area also has scattered wetlands $(<10 \%)$, which vary in extent and wetness according to season and climate conditions. Plant communities include tallgrass and mixed-grass prairie on rolling upland topography, bur oak (Quercus macrocarpa) savanna and quaking aspen (Populus tremuloides) stands on upland dunes, and sedge meadows and wetlands in low-lying areas. Low $(0.5-1 \mathrm{~m})$ shrubs, primarily western snowberry (Symphoricarpos occidentalis), are scattered throughout the mixed-grass prairie. A riparian deciduous forest dominated by basswood (Tilia americana), Eastern cottonwood (Populus deltoides), and willow (Salix spp.) occupies a portion of the study area. Grassland habitat is dominated by mixed grasses and forbs (Manske 1980, Seiler and Barker 1985). This study area varies from entirely open to densely wooded at the landscape scale (e.g., within 500-1000 m of bird observations). With its diverse habitat types, the area supports a wide variety of bird species, including open grassland species, deep woodland species, and species that occupy mixed or edgerich habitat (Cunningham et al. 2006, Martin and Svingen 2010).

The New York (NY) study area comprised public lands in a wooded region of eastern New York State's Hudson River Valley $(41.7 \mathrm{~N}, 73.7 \mathrm{~W})$. The region has expansive, mature second-growth deciduous forest. Bird surveys were limited to public lands in Dutchess County, for which detailed, digital land cover data were available. The county is largely wooded ( $75 \%$ of land cover), with mature, second-growth, mixed-deciduous forest dominated by oak (Quercus spp.), maple (Acer spp.), hickory (Carya spp.), and ash (Fraxinus spp.). Kiviat (1985) described the vegetation of the region in detail. Mixed herbaceous understory vegetation was abundant in most areas, except where white-tailed deer (Odocoileus virginianus) browsing had reduced understory density. DeOrsey and Butler (2010) have described the area's avifauna. Woodland bird species are largely similar in the two study areas, but in the New York study area, grassland birds are uncommon owing to the lack of open grassland, or agricultural land (DeOrsey and Butler 2010).

In the North Dakota study area, cultivated fields (mainly corn, soy, and potatoes) composed the majority of landcover surrounding the publicly owned grasslands. In the New York study area, mature second-growth forest composed nearly all of the surrounding land cover, with developed areas composing less than $10 \%$ of the county.

\section{Bird surveys}

Presence/absence data were collected using belt transects (Stewart and Kantrud 1972, Igl and Johnson 1997). One observer walked slowly $(\sim 1 \mathrm{~km} / \mathrm{hr})$ along a transect line, $1-6 \mathrm{~km}$ in length. All birds seen or heard within $50 \mathrm{~m}$ of the transect line were recorded, and a GPS unit was used to divide the transect into 100-m segments and to record bird observations within each 100-m segment. These segments were used to georeference bird occurrences to land cover data. Bird counts were done between half hour before sunrise and four hours after sunrise, between late May and early July from 2002 to 2005 (in ND) and May to late June 2009 (in NY). For the ND data, we pooled four years of data because preliminary analysis showed that year was not a significant effect and to average out minor variations among years (Cunningham and Johnson 2012). In four years we surveyed 3261 100-m transect segments. We analyzed species that were detected on 20 or more segments; of these, 40 species were associated with woodland or woodland edge, and 10 species were associated with open grassland in the ND study area (Table 1). In the NY study area there were 569 transect segments, $1-3.5 \mathrm{~km}$ long, and we analyzed 24 species that occurred 19 or more times (Table 2).

Table 1. Species names and number of transect segments on which species occurred in the North Dakota study area. Number of the $1002-6 \mathrm{~km}$ transects on which a species was observed is also shown.

\begin{tabular}{lcc}
\hline \hline Species name & N & $\begin{array}{c}\text { Number of } \\
\text { transects }\end{array}$ \\
\hline Grassland species & & \\
Killdeer (Charadrius vociferus) & 54 & 31 \\
Upland Sandpiper (Bartramia longicauda) & 78 & 52 \\
Marbled Godwit (Limosa fedoa) & 24 & 15 \\
Wilson's Snipe (Gallinago delicata) & 27 & 17 \\
Wilson's Phalarope (Phalaropus tricolor) & 50 & 21 \\
Sedge Wren (Cistothorus platensis) & 60 & 24 \\
Savannah Sparrow (Passerculus sandwichensis) & 402 & 57 \\
Grasshopper Sparrow (Ammodramus savannarum) & 1396 & 96 \\
Bobolink (Dolichonyx oryzivorus) & 148 & 58 \\
Western Meadowlark (Sturnella neglecta) & 409 & 87
\end{tabular}

Woodland species

Mourning Dove (Zenaida macroura) 323

Yellow-bellied Sapsucker (Sphyrapicus varius) 161

Hairy Woodpecker (Picoides villosus) $\quad 40$

Northern Flicker (Colaptes auratus) 88

Eastern Wood-Pewee (Contopus virens)

Willow Flycatcher (Empidonax traillii)

Least Flycatcher (Empidonax minimus)

Great Crested Flycatcher (Myiarchus crinitus)

Eastern Kingbird (Tyrannus tyrannus)

Yellow-throated Vireo (Vireo flavifrons)

Warbling Vireo (Vireo gilvus)

Red-eyed Vireo (Vireo olivaceus)

Blue Jay (Cyanocitta cristata)

Tree Swallow (Tachycineta bicolor)

Black-capped Chickadee (Poecile atricapillus)

White-breasted Nuthatch (Sitta carolinensis)

House Wren (Troglodytes aedon)

Eastern Bluebird (Sialia sialis)

Veery (Catharus fuscescens)

American Robin (Turdus migratorius)

Gray Catbird (Dumetella carolinensis)

Brown Thrasher (Toxostoma rufum)

European Starling (Sturnus vulgaris)

Cedar Waxwing (Bombycilla cedrorum)

Yellow Warbler (Setophaga petechia)

Black-and-white Warbler (Mniotilta varia)

Ovenbird (Seiurus aurocapilla)

Scarlet Tanager (Piranga olivacea)

Chipping Sparrow (Spizella passerina)

Field Sparrow ( Spizella pusilla)

Vesper Sparrow (Pooecetes gramineus)

Lark Sparrow (Chondestes grammacus)

Song Sparrow (Melospiza melodia)

Rose-breasted Grosbeak (Pheucticus ludovicianus)

Indigo Bunting (Passerina cyanea)

American Goldfinch (Spinus tristis)

Baltimore Oriole (Icterus galbula)

Orchard Oriole (Icterus spurius)

Common Grackle (Quiscalus quiscula)

Brown-headed Cowbird (Molothrus ater)

\begin{tabular}{lc}
23 & 86 \\
61 & 55 \\
40 & 29 \\
88 & 51 \\
31 & 57 \\
44 & 26 \\
38 & 70 \\
53 & 23 \\
65 & 83 \\
47 & 24 \\
33 & 51 \\
45 & 42 \\
75 & 38 \\
95 & 38 \\
62 & 36 \\
70 & 34 \\
61 & 77 \\
78 & 42 \\
21 & 9 \\
30 & 59 \\
61 & 58 \\
71 & 43 \\
29 & 23 \\
67 & 37 \\
205 & 54 \\
40 & 20 \\
18 & 30 \\
62 & 26 \\
38 & 21 \\
77 & 53 \\
00 & 78 \\
27 & 50 \\
33 & 23 \\
22 & 11 \\
25 & 16 \\
775 & 82 \\
96 & 69 \\
64 & 38 \\
95 & 43 \\
92 & 83 \\
\hline
\end{tabular}


Table 2. Species and number of transect segments on which a species occurred in New York study area. Species with 19 or more observations are listed. Number of the 28 1-3.5 km transects on which a species was observed is also shown.

\begin{tabular}{lcc}
\hline \hline Species name & $\mathrm{N}$ & $\begin{array}{c}\text { Number of } \\
\text { transects }\end{array}$ \\
\hline Red-bellied Woodpecker (Melanerpes & 21 \\
carolinus) & 38 & \\
Hairy Woodpecker (Picoides villosus) & 20 & 8 \\
American Crow (Corvus brachyrhynchos) & 26 & 16 \\
Great Crested Flycatcher (Myiarchus crinitus) & 55 & 13 \\
Eastern Wood-Pewee (Contopus virens) & 105 & 21 \\
Red-eyed Vireo (Vireo olivaceus) & 149 & 15 \\
Blue Jay (Cyanocitta cristata) & 60 & 23 \\
Black-capped Chickadee (Poecile atricapillus) & 54 & 13 \\
Tufted Titmouse (Baeolophus bicolor) & 58 & 21 \\
White-breasted Nuthatch (Sitta carolinensis) & 31 & 17 \\
Veery (Catharus fuscescens) & 112 & 19 \\
Wood Thrush (Hylocichla mustelina) & 86 & 24 \\
American Robin (Turdus migratorius) & 129 & 25 \\
Gray Catbird (Dumetella carolinensis) & 113 & 23 \\
Eastern Towhee (Pipilo erythrophthalmus) & 24 & 11 \\
Ovenbird (Seiurus aurocapilla) & 137 & 13 \\
Worm-eating Warbler (Helmitheros & 32 & 15 \\
vermivorum) & & \\
Blue-winged Warbler (Vermivora cyanoptera) & 21 & 8 \\
Scarlet Tanager (Piranga olivacea) & 96 & 23 \\
Chipping Sparrow (Spizella passerina) & 23 & 8 \\
Song Sparrow (Melospiza melodia) & 70 & 9 \\
Northern Cardinal (Cardinalis cardinalis) & 74 & 15 \\
Rose-breasted Grosbeak (Pheucticus & 19 & 14 \\
ludovicianus) & & \\
Brown-headed Cowbird (Molothrus ater) & 89 & 14 \\
\hline & & \\
& & \\
\hline
\end{tabular}

We used a conservative distance of $50 \mathrm{~m}$ to minimize variation in detectability, which can differ among species and habitat types, especially at distances beyond $100 \mathrm{~m}$ (Matsuoka et al. 2012). However, detection rates are high and consistent within $50 \mathrm{~m}$ (Simons et al. 2007, Koper et al. 2016), and a 50-m distance has been shown to provide reliable data for a broad range of species in both wooded and open habitats (Matsuoka et al. 2012). Studies of auditory-only detections have shown that estimated detection distances are subject to error (Alldredge et al. 2007), especially under windy or noisy conditions (Koper et al. 2016). To reduce these risks, we sampled only in weather conditions with little wind and no rain; other noise sources were minimal. A 50-m distance also ensured that we were sampling local habitat use, rather than landscape-scale habitat use. Field methods were described more fully by Cunningham and Johnson (2006).

\section{Habitat}

In a mixed landscape, there are many ways to describe terrestrial "habitat," including species composition, vegetation density, maturity, vertical structure, and other features; moreover, habitat for many birds includes multiple types of vegetation, such as combinations of trees, shrubs, and grasses. In studies aiming to explain site selection for individual species, detailed descriptors of these favored habitats can be essential. For multispecies characterizations and with digital land cover data analyzed at the landscape scale, however, it is often necessary to generalize cover types when more detailed features cannot reliably be distinguished. In our North Dakota study area, for example, grassland, which also includes a diversity of forbs and low shrubs, intergrades with shrub habitats and wet meadows and cannot reliably be distinguished in aerial imagery.

Consequently, landscape-scale studies often use land cover data that is generalized to a small number of classes, such as woodland and grassland, and habitat is often characterized in terms of the extent or abundance of tree cover (e.g., Andrén 1994, Freemark and Collins 1992, Parker et al. 2005, Radford et al. 2005, Desrochers et al. 2010). We followed this approach in the present study, although we recognize that for individual species there may be more detailed features that help explain habitat selection.

In land cover analysis, then, we use the term "grassland" to refer to open areas that may include a variety of forbs and low shrubs, and seasonal wet meadows and wetlands, which vary from year to year. These areas were dominated by grasses and forbs, and many wet meadows function similarly to grassland for many species; moreover, low shrubs and seasonal wetlands are not reliably distinguishable when digitizing land cover and so were not digitized or analyzed separately. We treat grassland as the converse of woodland, so that percentage grassland is 100 minus percentage woodland.

\section{Analytical methods}

For land cover analysis we used land cover data digitized from georeferenced aerial photographs with a pixel resolution of $1 \mathrm{~m}$; digitized data were then rasterized with a cell resolution of $5 \mathrm{~m}$. Past studies have shown that different species can respond to landscape conditions at different scales, and that a species' response can vary according to scales of analysis. To represent local, intermediate, and larger scales of analysis, we evaluated landscape composition within three distances, 200, 400, and 1200 $\mathrm{m}$, around each 100-m transect.

Previous work has shown that for woodland and edge species, percentage cover and edge density are stronger explanatory factors than are other metrics such as cohesion, core area, or patch size (Cunningham and Johnson 2012). Percentage tree cover has been useful for predicting the occurrence of both woodland birds (Dunford and Freemark 2005, Desrochers et al. 2010, Vetter et al. 2013) and grassland birds (Cunningham and Johnson 2006, Ribic et al. 2009a). As a preliminary assessment of explanatory effect of tree cover for the grassland birds analyzed here, we compared explanatory effects (using logistic regression) of percentage tree cover and edge density ( $m$ of woodland/grassland edge per ha) within $200 \mathrm{~m}$ for each of the species in the ND study area. For each species we used the following model: Probability of presence $=1-1 /\left[\exp \left(\beta_{0}+\beta_{1} X+\beta_{2} X^{2}\right)\right]$, where $X$ is either percentage tree cover or edge density. For grassland species, the mean logistic regression coefficient of determination $\left(\mathrm{R}^{2}\right)$ for percentage tree cover was 0.13 (range 0.07 to 0.24 ); for edge density, the mean $\mathrm{R}^{2}$ was 0.12 (range 0.06 to 0.25 ). For woodland species, the mean $\mathrm{R}^{2}$ for percentage tree cover was 0.14 (range 0.01 to 0.34 ); for edge density 0.13 (range 0.1 to 0.29 ). Thus we concluded that percentage tree cover was equivalent to or better than edge density in explanatory effect. Edge density is more sensitive to land cover data resolution, that is, to the degree of complexity in representation of landscape features, so we chose percentage tree cover as our landscape descriptor in analysis. 
For each species, we plotted probability of occurrence in relation to tree cover. We derived probability (or frequency) from presence/ absence data collected during our bird surveys as follows: We sorted all 100-m segments by percentage tree cover (within a given distance), and then grouped the sorted segments into roughly even-sized groups (42 groups of 76 observations and one of 69 for the ND data, and 10 groups of 58 observations and one of 56 for the NY data). We did this at three radii around segments (200, 400 , and $1200 \mathrm{~m}$ ) because species can respond to landscape composition differently at different scales, and we were interested in assessing whether effects were consistent at local $(200 \mathrm{~m})$ and landscape $(1200 \mathrm{~m})$ scales. For each group, at each scale, we then calculated the observed frequency of occurrence for each species and the average percentage tree cover. Using values of these group averages, we then were able to plot continuous data (rather than binary presence/absence values) for frequency of occurrence against percentage tree cover. We then fitted a curve to each plot using SAS PROC LOESS, a locally weighted regression and scatterplot smoothing method that calculated predicted probabilities of occurrence based on local regression (Cleveland and Devlin 1988, SAS Institute 2008). We used a standard smoothing parameter value of 0.5 . We calculated $95 \%$ confidence limits using the method of Cohen (1999), after confirming that residuals were approximately normally distributed. The resulting plots showed the estimated frequency of a species' occurrence along a gradient of tree cover. (All species were plotted against increasing tree cover, rather than increasing grass cover, for consistency.) In incidence plots, each point represents a group of observations used in calculating loess curves, and $\mathrm{X}$ values represent the average tree cover for those groups.

In order to quantify preferred ranges of tree cover and to compare stenotopicity in a large number of species, we calculated favored ranges of tree cover from incidence plots. By favored ranges we mean the amount of tree cover at which a species was most likely to occur. For woodland birds, one expects a species to occur most commonly at a higher percentage of tree cover. One species might be most likely to occur above $20 \%$ tree cover, for example, while another might be most likely to occur above $60 \%$. For grassland birds, one expects the favored range to be below some level of tree cover.

To aid comparison among species, we calculated this range as the range of tree cover where the frequency of occurrence was at least $50 \%$ of maximum frequency for that species. For example, Grasshopper Sparrows (for scientific names, see Table 1) occurred with a maximum frequency of 0.6 in groups used for incidence plots. For this species we identified the minimum and maximum tree cover at which frequency was at least half of that value, or 0.3 . This process can be done at any scale; we focused on the 200$\mathrm{m}$ scale for species comparisons because, although species respond to environmental conditions at a range of scales, incidence plots for 200-m and 400-m radii were similar (Figs. 2, 3 ), and responses were generally stronger at these scales than at the 1200-m scale. Favored ranges generalized the patterns of habitat selection shown in incidence plots, but they aided comparison among species.

\section{RESULTS}

Within $200 \mathrm{~m}$ of segments, the amount of woodland ranged from 0 to $84 \%$ (median $7 \%$ ) in ND and from 2 to $100 \%$ (median $88 \%$ ) in NY. Within a 1200-m radius, the amount of woodland ranged from 0 to $52 \%$ in ND (median $7 \%$ ) and 0 to $98 \%$ in NY (median $60 \%$ ). The most abundant species in ND were grassland birds (e. g. Grasshopper Sparrow and Western Meadowlark: Table 1), although mixed-landscape and woodland species also were numerous. Grassland species generally were absent from the NY study area (Table 2). A majority of species in both study areas occupied mixed habitat. We focus here on species with strongest preferences for either woodland or grassland habitat.

Of the four woodland species with narrowest patterns of habitat occupance in ND, two (Rose-breasted Grosbeak and Veery, Fig. 2), were absent or nearly absent up to around 20 to $30 \%$ tree cover, after which they increased with tree cover in an approximately linear fashion, consistent with line A in Figure 1. Two others (Black-and-white Warbler and Eastern Wood-Pewee) were more likely to occur at around $10 \%$ tree cover. These patterns persisted at larger radii. (For incidence plots for other woodland species, see Cunningham and Johnson 2012.)

The most stenotopic grassland species were very intolerant of tree cover. For Wilson's Snipe, Marbled Godwit, Savannah Sparrow, and Wilson's Phalarope, the likelihood of occurrence dropped to zero below $\sim 90 \%$ grassland (that is, beyond $\sim 10 \%$ tree cover) at all scales (Fig. 3). Six additional grassland species avoided landscapes with less than $70 \%$ grassland (more than $\sim 30 \%$ woodland: Figs. 3, 4). Again, patterns generally persisted at larger scales, with grassland birds generally absent in landscapes with less than $70-80 \%$ grassland (more than $20-30 \%$ tree cover) at the 1200-m scale. Most species declined more sharply than line B in Figure 1.

In general, incidence plots were dramatically different for woodland and grassland birds, even at larger radii. Thus stenotopicity is a consideration not just in areas immediately surrounding a species' breeding territory, but in much larger areas, for example within a $1200-\mathrm{m}$ radius around the nesting area of a Grasshopper Sparrow.

In the NY study area, all of the 10 most stenotopic species occurred in areas with less than 50\% tree cover (Fig. 5: we show only the 200-m scale because responses were similar or weaker at the larger scales). Only one species, the Worm-eating Warbler, had a pattern similar to those of most grassland species; it avoided open areas and was generally absent in areas less than $60 \%$ tree cover. For woodland species that occurred in both ND and NY study areas, plots were generally similar, although the sample sizes and uncertainty boundaries differed. The most stenotopic of the species that occurred in both areas, Veery and Ovenbird, tended to occur above $40 \%$ tree cover in both areas. Others occurred at 20 to $40 \%$ tree cover. Requirements for amount of suitable habitat were thus less restrictive for woodland birds, and requirements were similar in both study areas. Grassland species were too few to analyze in the NY study area.

In plots of preferred ranges for ND, 10 grassland species primarily occupied habitat with more than $85 \%$ grassland (that is, less than $15 \%$ tree cover, Fig. 6). The nine most stenotopic woodland birds occurred with at least $60-65 \%$ tree cover. (Because the ND study site had few areas with $100 \%$ tree cover, Figure 6 does not extend beyond $75 \%$ tree cover on the $\mathrm{X}$ axis.) Species exhibited a spectrum of habitat selection patterns, with most occupying mixed habitat 
Fig. 2. Responses at three scales for five species with the strongest positive responses to woodlands in the North Dakota study area. Species are sorted in order of narrowness of habitat preference (see Fig. 6). Points represent groups used in calculating loess curves (solid lines) and 95\% confidence intervals (dashed lines).
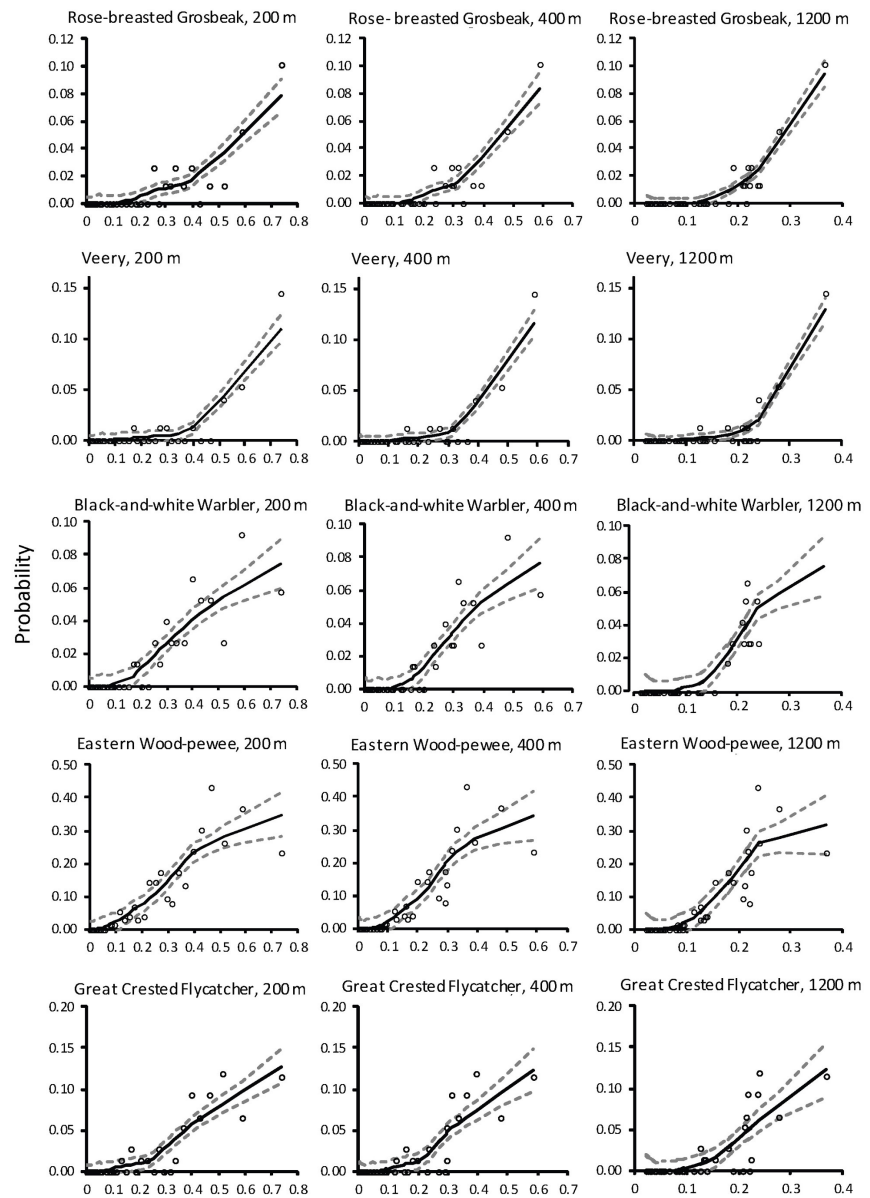

Percentage tree cover
Fig. 3. Responses at 3 scales for 5 of 10 grassland species in the North Dakota study area. Species are sorted in order of narrowness of habitat preference.
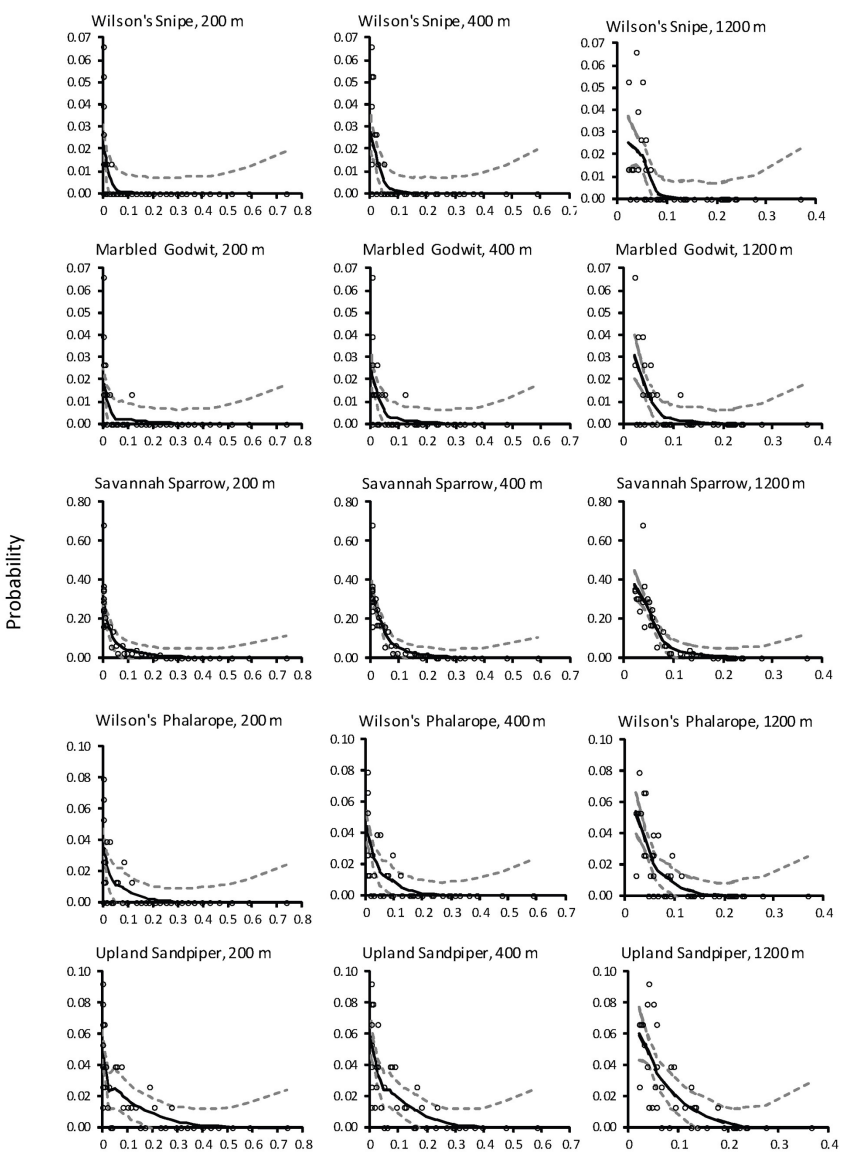

Percentage tree cove types. Among species preferring wooded habitat, a smaller proportion had narrow ranges, and these ranges represented less precipitous slopes in incidence plots (Figs. 2-4).

In plots of preferred ranges for NY, three of the 24 species were most likely to occur with more than $90 \%$ tree cover (Worm-eating Warbler, Ovenbird, and Veery: Fi. 7). As in ND, ranges were widest for species that occupied mixed habitat, such as the Blue-winged Warbler, Eastern Towhee, and American Robin.

\section{DISCUSSION}

Intolerance of unsuitable habitats appears to be even more important for grassland birds than for woodland birds, as indicated by patterns in incidence plots and by the proportion of species with narrow preferred ranges. In incidence plots, grassland birds tended to occur in much narrower ranges. Many grassland species frequently required at least $70-90 \%$ grassland in the landscape, whereas most woodland birds required only $10-40 \%$ tree cover.
These levels are similar to thresholds reported by previous studies for woodland birds (Radford et al. 2005, Betts et al. 2010, 2014, Zuckerberg and Porter 2010). Few comparable studies of thresholds in habitat availability and occupancy were available for grassland birds. Favored ranges provide another way to visualize differences: Ten ND species (of 40 that occupied open or partially open landscapes) had favored ranges greater than $85 \%$ grassland, while 3 of 24 woodland species in NY (and none in ND) had preferred ranges greater than $85 \%$ woodland. Overall, these patterns do not support our null hypothesis that stenotopicity is equivalent in the two groups. Whereas woodland species tolerated a considerable degree of fragmentation in woodland habitat, even modest degrees of grassland fragmentation (presence of tree cover) can evidently make habitat unsuitable for some grassland species.

Differences in tolerance in grassland birds were supported by the comparison of study areas. In particular, it could be that low stenotopicity (a wider range of tolerance) in ND woodland birds 
Fig. 4. Responses at 3 scales for 5 of 10 grassland species in Fig. 5. Incidence plots for the 10 most area-sensitive species in the New the North Dakota study area. Species are sorted in order of York data set, with plots for the same species in North Dakota shown for narrowness of habitat preference.
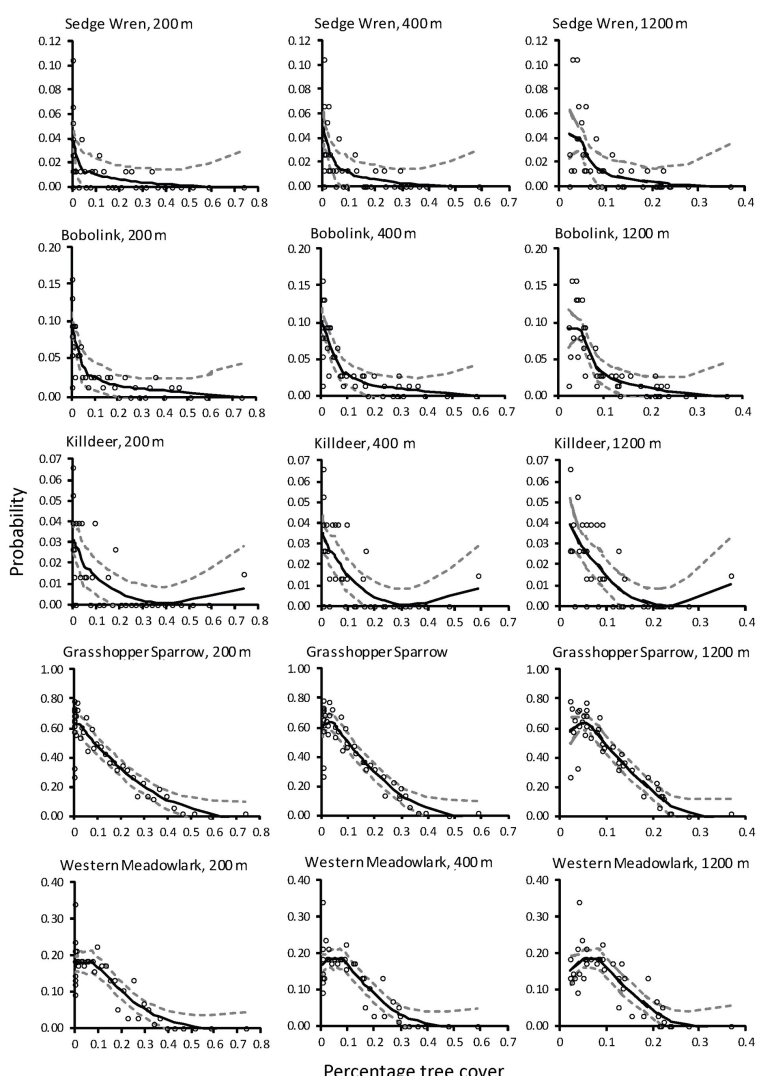
comparison. Vertical axes for ND are set to match those of NY plots. Species are sorted in order of decreasing area sensitivity (see Fig. 7).

"NA" indicates species that were absent in ND.
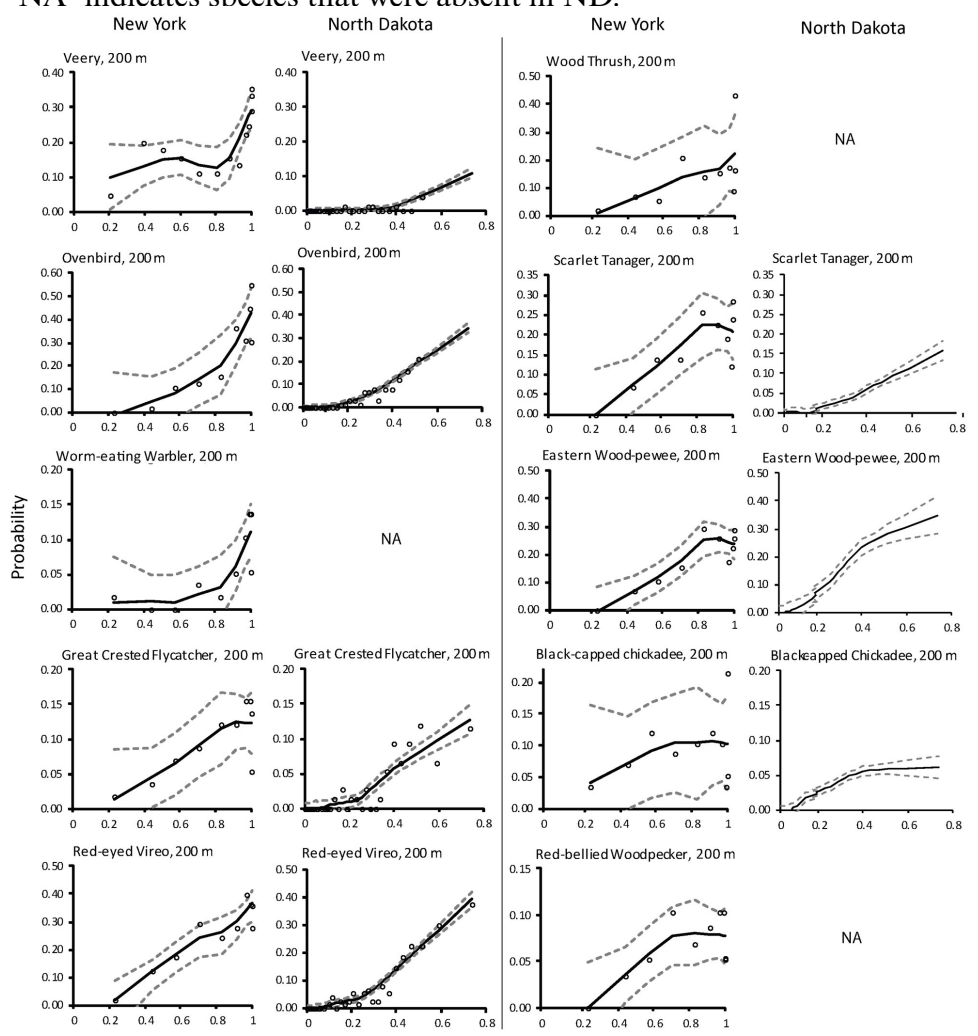

NA

Percentage tree cover

was simply a response to lower abundance of trees in the ND landscape. However, woodland birds had similar patterns of occurrence in the two study areas, so the difference in study areas does not adequately explain the difference in habitat response between woodland and grassland birds. The contrast between woodland and grassland birds also did not reflect an absence of "interior" woodland species from the study. Betts et al. (2010) found occurrence thresholds of $30 \%$ or less for woodland birds, and a number of woodland species examined here have been described as interior woodland species elsewhere; for example the Veery, Wood Thrush, Ovenbird, and Rose-breasted Grosbeak have been described as area sensitive (Robbins et al. 1989, Villard 1998, Parker et al. 2005, Desrochers et al. 2010). All of these species occurred in both study areas. The NY study area did have several woodland species that were absent from the ND study area, but only one of these (Worm-eating Warbler) had stenotopicity similar to that of the nine most stenotopic grassland species.

Although grassland birds showed more stenotopicity and thus have particular conservation concerns, woodland birds also face critical habitat losses, reduced habitat, and forest fragmentation. Multiple factors lead to both loss and degradation of both woodland and grassland habitat. Many woodland birds also have very specific habitat requirements, in breeding, migratory, and wintering grounds. Our findings should be interpreted not as diminishing problem of woodland fragmentation but as drawing attention to the effects of grassland fragmentation.

Intolerance of fragmentation is an important consideration in species conservation, and the observations made here should contribute to understanding of this intolerance in different species, groups of species, and environments. We suggest that for examining multiple species in a mixed landscape, or for examining species that occupy the dominant "matrix" component of a landscape, stenotopicity is a useful concept. It is related to the more commonly used idea of area sensitivity, as used by Desrochers et al. (2010) to mean requirements of large amounts of habitat. In complex landscapes, assessing stenotopicity aids comparison of species on a continuum of responses.

It is beyond the scope of this paper to explain why grassland birds are more stenotopic than woodland birds, but previous authors have pointed out that grassland birds evolved in North America's Great Plains (Udvardy 1958, Mengel 1970, Knopf 1996), where trees were virtually absent. In addition to trees being evolutionarily unfamiliar to grassland birds, in more recent times trees have served 
Fig. 6. Favored ranges derived from incidence plots in North Dakota. The $\mathrm{X}$ axis extends only to $75 \%$ tree cover.

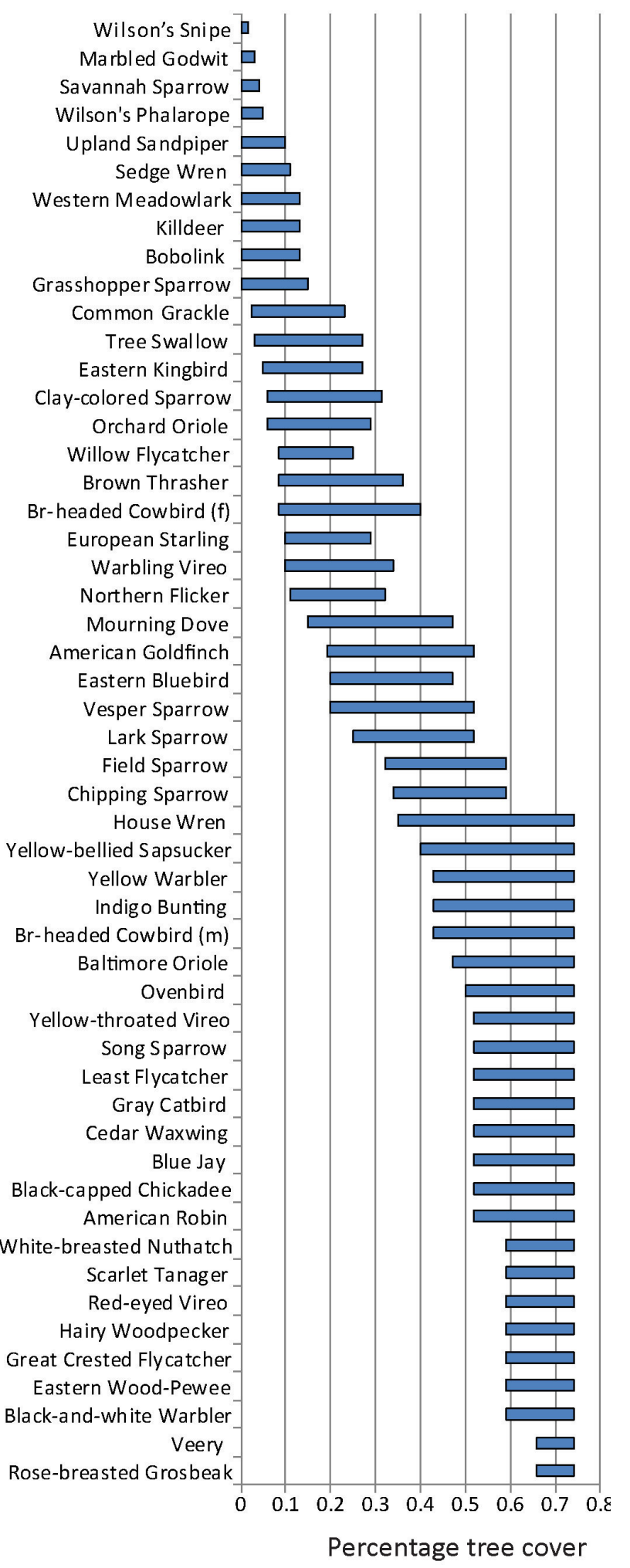

Fig. 7. Favored ranges derived from incidence plots in New York.

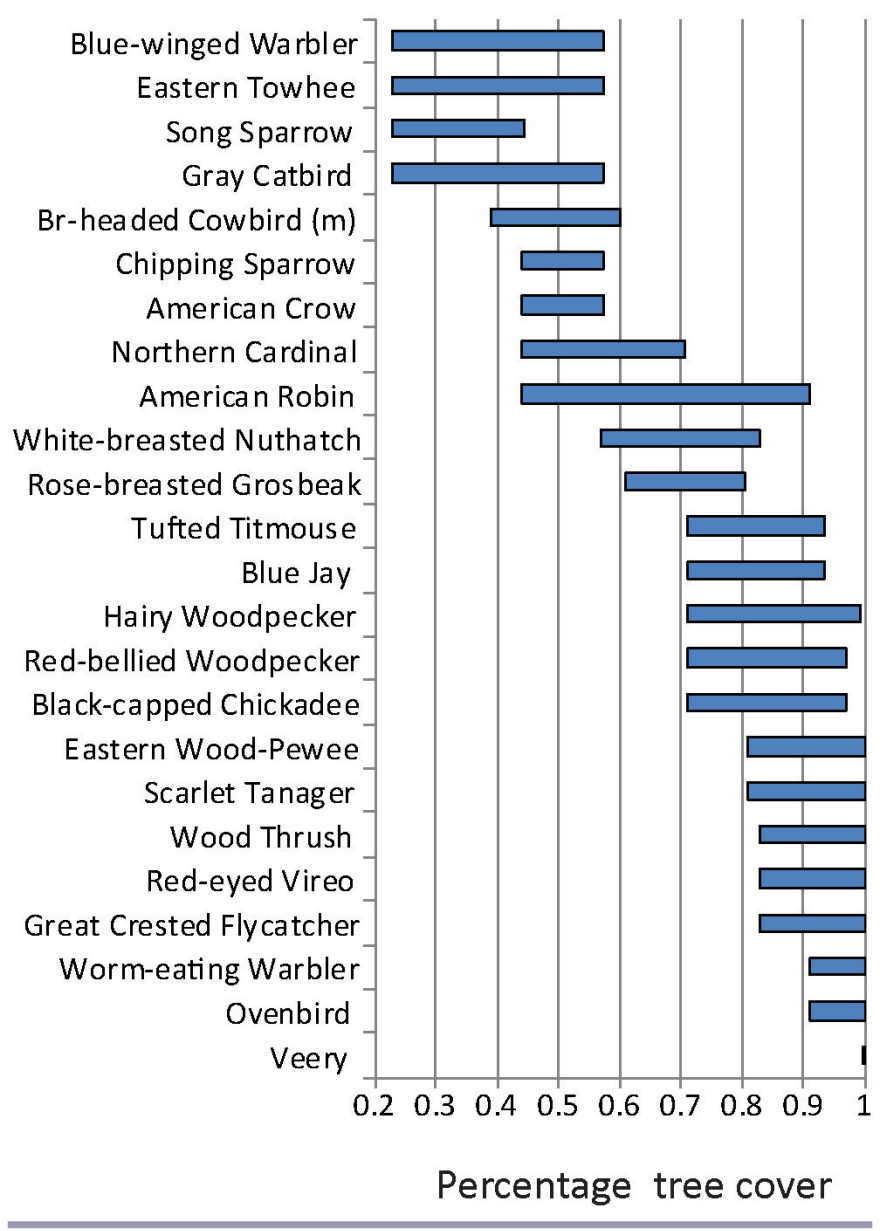

as perch sites for avian predators and brood-parasitic Brownheaded Cowbirds as well as habitat for woodland predators (Ellison et al. 2013). Trees may thus serve as visual cues of predator risk for open-country birds. Even a few trees in an open landscape can support woodland-associated predators. In contrast, a few open areas in a forested landscape would be unlikely to have similar effects; predators that avoid woods would not be inclined to enter such woods even if they would inhabit open areas within the woods.

We conclude that grassland birds face a double vulnerability from high rates of habitat loss (Faber et al. 2012) and high sensitivity to fragmentation. This combination is likely to help explain the frequently noted population declines in grassland birds, which exceed those of species in other habitat types (Sauer et al. 2017). Some studies have argued that widespread habitat loss may be dire for grassland species, and that many may not be viable with current habitat availability (Samson et al. 2004, With et al. 2008). This study similarly highlights the importance of attention to conservation of grassland habitat. Although most habitat types are threatened in the North America, there has been some regional expansion of forest cover in recent decades, especially with the decline of agriculture in eastern regions (Ramankutty et al. 2010, Sohl et al. 2016). Wetlands remain at risk, but losses have slowed with legal protections in many areas. Grasslands, on the other hand, have few 
legal protections and are changing more rapidly than other classes of land cover (Drum et al. 2015).

Rising crop prices in recent years have led to further reductions in remnant grassland, such as field edges, hay fields, set-aside farmlands, and pasture. With the loss of over $70 \%$ of North America's grasslands, grassland birds increasingly rely on habitat that is privately owned and managed for livestock production or agriculture (Samson et al. 2004, Faber et al. 2012). Mounting pressure to expand agricultural production on these lands, including biofuel production incentives and other crop supports, further exacerbates the risks to grassland birds in North America (Wiens et al. 2011, Faber et al. 2012). In addition, new factors such as solar farms are creating additional demands for open lands. These facilities are likely to be modest in comparison to crop fields, but they may be worth watching as an additional demand on remnant fragments of grassland. Thus it is essential to understand better the combined impacts of agricultural expansion on grassland habitat and narrowness of habitat requirements to aid conservation of bird populations in what grasslands remain.

Responses to this article can be read online at: http://www.ace-eco.org/issues/responses.php/1372

\section{Acknowledgments:}

We thank T. Finkle and L. Walker DeVore for assistance in this work. This study was supported and assisted by D. Svingen and B. Stotts at the U.S. Forest Service, Dakota Prairie Grasslands; USGS Northern Prairie Wildlife Research Center; and funding from the Vassar College Environmental Research Institute.

\section{LITERATURE CITED}

Alldredge, M. W., T. R. Simons, and K. H. Pollock. 2007. A field evaluation of distance measurement error in auditory avian point count surveys. Journal of Wildlife Management 71:2759-2766. https://doi.org/10.2193/2006-161

Andrén, H. 1994. Effects of habitat fragmentation on birds and mammals in landscapes with different proportions of suitable habitat: a review. Oikos 71:355-366. https://doi.org/10.2307/3545823

Barton, E. P., S. E. Pabian, and M. C. Brittingham. 2016. Bird community response to Marcellus Shale gas development. Journal of Wildlife Management 80:1301-1313. https://doi.org/10.1002/ jwmg.21117

Beck, J. J., M. J. McKone, and O. S. McMurtrey. 2016. Edge effects and avian community structure in a restored tallgrass prairie. Natural Areas Journal 36:328-333. https://doi.org/10.3375/043.036.0313

Betts, M. G., L. Fahrig, A. S. Hadley, K. E. Halstead, J. Bowman, W. D. Robinson, J. A. Wiens, and D. B. Lindenmayer. 2014. A species-centered approach for uncovering generalities in organism responses to habitat loss and fragmentation. Ecography 37:517-527. https://doi.org/10.1111/ecog.00740

Betts, M. G., J. C. Hagar, J. W. Rivers, J. D. Alexander, K. M. McGarigal, and B. C. McComb. 2010. Thresholds in forest bird occurrence as a function of the amount of early-seral broadleaf forest at landscape scales. Ecological Applications 20:2116-2130. https://doi.org/10.1890/09-1305.1

Cleveland, W. S., and S. J. Devlin. 1988. Locally weighted regression: an approach to regression analysis by local fitting. Journal of the American Statistical Association 83:596-610. https://doi.org/10.1080/01621459.1988.10478639

Cohen, R. A. 1999. An introduction to PROC LOESS for local regression. Proceedings of the 24th SAS Users Group International Conference, Paper 273. SAS Institute Inc., Cary, North Carolina, USA.

Cunningham, M. A., and D. H. Johnson. 2006. Proximate and landscape factors influence grassland bird distributions. Ecological Applications 16:1062-1075.

Cunningham, M. A., and D. H. Johnson. 2012. Habitat selection and ranges of tolerance: how do species differ beyond critical thresholds? Ecology and Evolution 2:2815-2828. https://doi. org/10.1002/ece3.394

Cunningham, M. A., and D. H. Johnson. 2016. What you find depends on where you look: responses to proximate habitat vary with landscape context. Avian Conservation and Ecology 11(2):1. http://dx.doi.org/10.5751/ACE-00865-110201

Cunningham, M. A., D. H. Johnson, and D. N. Svingen. 2006. Estimates of breeding bird populations in the Sheyenne National Grassland, North Dakota. Prairie Naturalist 38:39-61.

DeOrsey, S., and B. A. Butler. 2010. The birds of Dutchess County New York, today and yesterday. Ralph T. Waterman Bird Club Inc., Poughkeepsie, New York, USA. [online] URL: http:// watermanbirdclub.org/publications/the-birds-of-dutchess-countyny

Desrochers, A., C. Renaud, W. M. Hochachka, and M. Cadman. 2010. Area-sensitivity by forest songbirds: theoretical and practical implications of scale-dependency. Ecography 33:921-931. https://doi.org/10.1111/j.1600-0587.2009.06061.x

Donovan, T. M., and C. H. Flather. 2002. Relationships among North American songbird trends, habitat fragmentation, and landscape occupancy. Ecological Applications 12:364-374. https:// doi.org/10.2307/3060948

Drum, R. G., C. A. Ribic, K. Koch, E. Lonsdorf, E. Grant, M. Ahlering, L. Barnhill, T. Dailey, S. Lor, C. Mueller, D. C. Pavlacky Jr., C. Rideout, and D. Sample. 2015. Strategic grassland bird conservation throughout the annual cycle: linking policy alternatives, landowner decisions, and biological population outcomes. PLoS ONE 10(11):e0142525. http://doi.org/10.1371/ journal.pone. 0142525

Dunford, W., and K. Freemark. 2005. Matrix matters: effects of surrounding land uses on forest birds near Ottawa, Canada. Landscape Ecology 20:497-511. https://doi.org/10.1007/s10980-004-5650-5

Ellison, K. S., C. A. Ribic, D. W. Sample, M. J. Fawcett, and J. D. Dadisman. 2013. Impacts of tree rows on grassland birds and potential nest predators: a removal experiment. PLOS ONE 8(4): e59151. http://doi.org/10.1371/journal.pone.0059151

Faber, S., S. Rundquist, and T. Male. 2012. Plowed under: how crop subsidies contribute to massive habitat losses. Environment 
Working Group, Washington, D.C., USA. [online] URL: http:// static.ewg.org/pdf/plowed_under.pdf

Freemark, K., and B. Collins. 1992. Landscape ecology of birds breeding in temperate forest fragments. Pages 443-454 in J. M. Hagan and D. W. Johnston, editors. Ecology and Conservation of Neotropical Migrant Landbirds. Smithsonian Institution, Washington, D.C., USA.

Grant, T. A., E. Madden, and G. B. Berkey. 2004. Tree and shrub invasion in northern mixed-grass prairie: implications for breeding grassland birds. Wildlife Society Bulletin 32:807-818.

Hamilton, L. E., B. C. Dale, and C. A. Paszkowski. 2011. Effects of disturbance associated with natural gas extraction on the occurrence of three grassland songbirds. Avian Conservation and Ecology 6(1):7. http://dx.doi.org/10.5751/ACE-00458-060107

Herkert, J. R. 1994. The effects of habitat fragmentation on midwestern grassland bird communities. Ecological Applications 4:461-471. http://dx.doi.org/10.2307/1941950

Hill, J. M., J. F. Egan, G. E. Stauffer, and D. R. Diefenbach. 2014. Habitat availability is a more plausible explanation than insecticide acute toxicity for U.S. grassland bird species declines. PLoS ONE 9(5):e98064. http://doi.org/10.1371/journal.pone.0098064

Igl, L. D., and D. H. Johnson. 1997. Changes in breeding bird populations in North Dakota: 1967 to 1992-93. Auk 114:74-92. https://doi.org/10.2307/4089067

Johnson, D. H. 1996. Management of northern prairies and wetlands for the conservation of neotropical migratory birds. Pages 53-67 in F. R. Thompson, III, editor. Management of Midwestern landscapes for the conservation of neotropical migratory birds. U.S. Forest Service General Technical Report NC-187. North Central Forest Experiment Station, St. Paul, Minnesota, USA.

Johnson, D. H. 2001. Habitat fragmentation effects on birds in grasslands and wetlands: a critique of our knowledge. Great Plains Research 11:211-231.

Johnson, D. H., and L. D. Igl. 2001. Area requirements of grassland birds: a regional perspective. $A u k$ 118:24-34. https://doi. org/10.1642/0004-8038(2001)118[0024:AROGBA]2.0.CO;2

Johnson, R. G., and S. A. Temple. 1990. Nest predation and brood parasitism of tallgrass prairie birds. Journal of Wildlife Management 54:106-111. https://doi.org/10.2307/3808909

Kiviat, E. 1985. Vegetation. Pages 101-122 in H. Thomas, editor. Dutchess County, New York: Natural Resources. Department of Planning, Dutchess Environmental Management Council, Poughkeepsie, New York, USA. [online] URL: https:// dutchessemc.org/projects/dutchess-county-nri/1985-nri/

Knopf, F. L. 1996. Prairie legacies-birds. Pages 1135-148 in F. B. Samson and F. L. Knopf, editors. Preserving North America's most endangered ecosystem. Island Press, Washington, D.C., USA.

Koper, N., L. Leston, T. M. Baker, C. Curry, and P. Rosa. 2016. Effects of ambient noise on detectability and localization of avian songs and tones by observers in grasslands. Ecology and Evolution 6:245-255. https://doi.org/10.1002/ece3.1847
Manske, L. L. 1980. Habitat, phenology and growth of selected sandhill range plants. Dissertation. North Dakota State University, Fargo, North Dakota, USA.

Martin, R., and D. Svingen. 2010. Bird status and distribution on the Sheyenne National Grassland. Report to Dakota Prairie Grasslands. Internal report U.S. Forest Service, Bismarck, North Dakota, USA.

Matsuoka, S. M., E. M. Bayne, P. Sólymos, P. C. Fontaine, S. G. Cumming, F. K. A. Schmiegelow, and S. J. Song. 2012. Using binomial distance-sampling models to estimate the effective detection radius of point-count surveys across boreal Canada. Auk 129:268-282. https://doi.org/10.1525/auk.2012.11190

McWethy, D. B., A. J. Hansen, and J. P. Verschuyl. 2009. Edge effects for songbirds vary with forest productivity. Forest Ecology and Management 257:665-678. http://dx.doi.org/10.1016/j. foreco.2008.09.046

Mengel, R. M. 1970. The North American Central Plains as an isolating agent in bird speciation. Pages 280-340 in W. Dort and J. K. Jones, editors. Pleistocene and recent environments of the central Great Plains. University of Kansas Press, Lawrence, Kansas, USA.

North American Bird Conservation Initiative (NABCI), U.S. Committee. 2014. The state of the birds 2014 report. U.S. Department of the Interior, Washington, D.C., USA. [online] URL: http://www.stateofthebirds.org/2014/2014\%20SotB_FINAL_lowres.pdf

Parker, T. H., B. M. Stansberry, C. D. Becker, and P. S. Gipson. 2005. Edge and area effects on the occurrence of migrant forest songbirds. Conservation Biology 19:11157-1167. https://doi. org/10.1111/j.1523-1739.2005.00107.x

Radford, J. Q., A. F. Bennett, and G. J. Cheers. 2005. Landscapelevel thresholds of habitat cover for woodland-dependent birds. Biological Conservation 124:317-337. https://doi.org/10.1016/j. biocon.2005.01.039

Ramankutty, N., E. Heller, and J. Rhemtulla. 2010. Prevailing myths about agricultural abandonment and forest regrowth in the United States. Annals of the Association of American Geographers 100:502-512. http://doi.org/10.1080/00045601003788876

Ribic, C. A., M. J. Guzy, and D. W. Sample. 2009b. Grassland bird use of remnant prairie and Conservation Reserve Program fields in an agricultural landscape in Wisconsin. American Midland Naturalist 161:110-122. https://doi.org/10.1674/0003-0031-161.1.110

Ribic, C. A., R. R. Koford, J. R. Herkert, D. H. Johnson, N. D. Niemuth, D. E. Naugle, K. K. Bakker, D. W. Sample, and R. B. Renfrew. 2009a. Area sensitivity in North American grassland birds: patterns and processes. Auk 126:233-244. https://doi. org/10.1525/auk.2009.1409

Rittenhouse, C. D., A. M. Pidgeon, T. P. Albright, P. D. Culbert, and M. K. Clayton, C. H. Flather, C. Huang, J. G. Masek, S. I. Stewart, and V. C. Radeloff. 2010. Conservation of forest birds: evidence of a shifting baseline in community structure. PLoS ONE 5(8):e11938. http://doi.org/10.1371/journal.pone.0011938 
Robbins, C. S., D. K. Dawson, and B. A. Dowell. 1989. Habitat area requirements of breeding forest birds of the Middle Atlantic states. Wildlife Monographs 103:1-34.

Robinson, S. K. 1995. Threats to breeding Neotropical migratory birds in the Midwest. Pages 1-21 in F. R. Thompson, III, editor. Management of Midwestern landscapes for the conservation of Neotropical migratory birds. U.S. Forest Service General Technical Report NC-187. North Central Forest Experiment Station, St. Paul, Minnesota, USA.

Samson, F. B., F. L. Knopf, and W. Ostlie. 2004. Great Plains ecosystems: past, present and future. Wildlife Society Bulletin 32:6-15. https://doi.org/10.2193/0091-7648(2004)32[6:GPEPPA] 2.0.CO;2

SAS Institute. 2008. SAS/STAT software, release 9.1. SAS Institute, Cary, North Carolina, USA.

Sauer, J. R., D. K. Niven, J. E. Hines, D. J. Ziolkowski, Jr, K. L. Pardieck, J. E. Fallon, and W. A. Link. 2017. The North American Breeding Bird Survey, results and analysis 1966-2015. Version 2.07.2017. U.S. Geological Survey Patuxent Wildlife Research Center, Laurel, Maryland, USA. [online] URL: http://www.mbrpwrc.usgs.gov/bbs/bbs.html

Seiler, G. J. W., and T. Barker. 1985. Vascular flora of Ransom, Richland and Sargent counties, North Dakota. Prairie Naturalist 17:193-240.

Simons, T. R., M. W. Alldredge, K. H. Pollock, and J. M. Wettroth. 2007. Experimental analysis of the auditory detection process on avian point counts. Auk 124:986-999. https://doi.org/10.1642/0004-8038 (2007)124[986:EAOTAD]2.0.CO;2

Sohl, T., R. Reker, M. Bouchard, K. Sayler, J. Dornbierer, S. Wika, R. Quenzer, and A. Friesz. 2016. Modeled historical land use and land cover for the conterminous United States. Journal of Land Use Science 11:476-499. https://doi.org/10.1080/1747423X.2016.1147619

Stewart, R. E., and H. A. Kantrud. 1972. Population estimates of breeding birds in North Dakota. Auk 89:766-788. https://doi. org/10.2307/4084108

Suarez-Rubio, M., S. Wilson, P. Leimgruber, and T. Lookingbill. 2013. Threshold responses of forest birds to landscape changes around exurban development. PLoS ONE 8(6):e67593. http:// doi.org/10.1371/journal.pone.0067593

Thomas, E. H., M. C. Brittingham, and S. H. Stoleson. 2014. Conventional oil and gas development alters forest songbird communities. Journal of Wildlife Management 78:293-306. https:// doi.org/10.1002/jwmg.662

Udvardy, M. D. F. 1958. Ecological and distributional analysis of North American birds. Condor 60:50-66. https://doi. org/10.2307/1365706
Vetter, D., G. Rücker, and I. Storch. 2013. A meta-analysis of tropical forest edge effects on bird nest predation risk: edge effects in avian nest predation. Biological Conservation 159:382-395. https://doi.org/10.1016/j.biocon.2012.12.023

Villard, M.-A. 1998. On forest-interior species, edge avoidance, area sensitivity, and dogmas in avian conservation. Auk 115:801-805. https://doi.org/10.2307/4089434

Whitcomb, R. F., C. S. Robbins, J. F. Lynch, B. L. Whitcomb, M. K. Klimkiewicz, and D. Bystrak. 1981. Effects of forest fragmentation on avifauna of the eastern deciduous forest. Pages 125-205 in R. L. Burgess and D. M., Sharpe, editors. Forest Island dynamics in man-dominated landscapes. Springer-Verlag, New York, New York, USA.

Wiens, J. A., J. Farione, and J. Hill. 2011. Biofuels and biodiversity. Ecological Applications 21:1085-1095. https://doi.org/10.1890/09-0673.1

Winter, M., D. H. Johnson, and J. Faaborg. 2000. Evidence for edge effects on multiple levels in tallgrass prairie. Condor 102:256-266. https://doi.org/10.1650/0010-5422(2000)102[0256: EFEEOM]2.0.CO;2

With, K. A., A. W. King, and W. E. Jensen. 2008. Remaining large grasslands may not be sufficient to prevent grassland bird declines. Biological Conservation 141:3152-3167. https://doi.org/10.1016/j. biocon.2008.09.025

Zuckerberg, B., and W. F. Porter. 2010. Thresholds in the longterm responses of breeding birds to forest cover and fragmentation. Biological Conservation 143:952-962. https://doi. org/10.1016/j.biocon.2010.01.004
Editor-in-Chief: Keith A.Hobson Subject Editor: Erica Nol
Sponsored by the Society of Canadian Ornithologists and Bird Studies Canada Parrainée par la Société des ornithologistes $d u$ Canada et Etudes d'oiseaux Canada 